\title{
The construction and quantification of rural housing performance evaluation index system
}

\author{
Zhang Zhaochang ${ }^{1, \text { a }}$; Fan Xuhong ${ }^{2}$; Cao Lilin ${ }^{3}$; Yang Fan ${ }^{4}$; Li Yanrong ${ }^{5}$; \\ ${ }^{1}$ Faculty of civil engineering and mechanics, Jiangsu University, ZHENG JIANG,212013, China \\ a1538719276@qq.com
}

Keywords: Rural housing ; Performance evaluation; Index system ; Index quantification

\begin{abstract}
The performance evaluation index system of rural houses is put forward, considering of factors not only one of housing safety, comfort, convenience, and human nature , but also comprehensively four factors . By a lot of investigation, combined with the standards , building physics, the index is quantized to provide numerical value of the performance. The weight of each performance index is determined by Grey-AHP. Then the performance evaluation model of the rural houses is established to provide quantitative basis for housing performance evaluation.
\end{abstract}

\section{Introduction}

Rural housing is the basis for the lives of rural residents, and housing performance is directly related to the quality of residents' life and rural construction appearance. For a long time, China's rural housing construction process is such lack of design, construction guidance that rural housing exposed the two major problems, safety and comfort problem. Especially since 1990s, rural housing has a huge impact by urbanization, including housing demolition, local building demolition, city building elements invasion, causing destruction of the original culture and rural architectural style ${ }^{[1,2]}$.

In this paper, the rural housing performance evaluation index is proposed and quantified. Then, the weight each index is determined by grey AHP and the rural housing performance evaluation model is established to provide quantitative basis for housing performance evaluation and promotion.

\section{The construction of rural housing performance evaluation index system}

Reasonable rural housing performance system is the key of housing performance evaluation and promotion. The selection of evaluation indicators should consider all aspects of the housing to ensure that the indicators are comprehensive, critical, oriented, operational.

Based on a lot of research on the performance of the existing rural housing, the major factors are reflected including the safety, comfort, convenience, humanization and comprehensive four performance, which are the goal of the evaluation to enhance the performance of the house. Primary indicators of housing performance include four second level index and twelve third level indicators, seeing Tab 1.

Tab 1 The performance evaluation index system of rural houses

\begin{tabular}{|c|c|c|c|c|c|c|c|c|c|c|c|c|c|c|}
\hline $\begin{array}{l}\text { First } \\
\text { index }\end{array}$ & \multicolumn{14}{|c|}{ Performance objectives of rural housing $U$} \\
\hline $\begin{array}{c}\text { Second } \\
\text { index } \\
U_{i}\end{array}$ & \multicolumn{5}{|c|}{$\begin{array}{l}\text { Safety performance } \\
U_{1}\end{array}$} & \multicolumn{5}{|c|}{$\begin{array}{l}\text { Comfortable performance } \\
\qquad U_{2}\end{array}$} & \multicolumn{2}{|c|}{$\begin{array}{c}\text { Convenient } \\
\text { performance } \\
\cup_{3}\end{array}$} & \multicolumn{2}{|c|}{$\begin{array}{c}\text { Humanizational } \\
\text { performance } \\
U_{4}\end{array}$} \\
\hline $\begin{array}{l}\text { Third } \\
\text { index } \\
\text { Uij }\end{array}$ & $\begin{array}{l}\text { Struct } \\
\text {-ure } \\
\text { secur } \\
\text {-ity } \\
U_{11}\end{array}$ & $\begin{array}{c}\text { Fire } \\
\text { safety } \\
\text { secur } \\
\text {-ity } \\
U_{12}\end{array}$ & $\begin{array}{l}\text { Water } \\
\text { secur } \\
\text {-ity } \\
U_{13}\end{array}$ & $\begin{array}{c}\text { Electri } \\
\text {-cal } \\
\text { secur } \\
\text {-ity } \\
U_{14}\end{array}$ & $\begin{array}{l}\text { Daily } \\
\text { secur } \\
\text {-ity } \\
U_{15}\end{array}$ & $\begin{array}{c}\text { Wind } \\
\text { environ } \\
\text {-ment } \\
U_{21}\end{array}$ & $\begin{array}{l}\text { Hot and } \\
\text { humid } \\
\text { environ } \\
\text {-ment } \\
U_{22}\end{array}$ & $\begin{array}{c}\text { Light } \\
\text { environ } \\
\text {-ment } \\
\cup_{23}\end{array}$ & $\begin{array}{c}\text { Acoustic } \\
\text { environ } \\
\text {-ment } \\
U_{24}\end{array}$ & $\begin{array}{c}\text { Air } \\
\text { quality } \\
\mathrm{U}_{25}\end{array}$ & $\begin{array}{l}\text { Infrastr } \\
\text {-ucture } \\
U_{31}\end{array}$ & $\begin{array}{c}\text { Indoor } \\
\text { facilities } \\
\mathrm{U}_{32}\end{array}$ & $\begin{array}{l}\text { Activity } \\
\text { space } \\
\cup_{41}\end{array}$ & $\begin{array}{c}\text { Habits } \\
\text { and } \\
\text { custom } \\
\mathrm{S} \\
\mathrm{U}_{42}\end{array}$ \\
\hline
\end{tabular}




\section{The numerical quantification of rural housing performance index}

By a lot of investigation, combined with the standards, building physics, the numerical value of the performance index is quantized to provide quantitative basis for the evaluation, Seeing Tab 2.

Tab2 Numerical quantization of performance indexes of village houses

\begin{tabular}{|c|c|}
\hline $\begin{array}{l}\text { ird index } \\
\text { Uij }\end{array}$ & Evaluation content (points) \\
\hline $\begin{array}{c}\text { Structure } \\
\text { security } \\
U_{11}\end{array}$ & $\begin{array}{l}\text { (1) Earthquake intensity: less than or equal to VI degrees , } 2.5 \text { points; VII degrees , } 2 \text { points ; } \\
\text { VIII degrees , } 1.5 \text { points ; IX degrees , } 1.5 \text { points ; more than IX degrees , } 0 \text { points ; } \\
\text { (2) The structure type: steel and reinforced concrete structure , } 3 \text { points; brick concrete } \\
\text { structure, } 2 \text { points (if it has construction column and circle beam, }+1 \text { point); brick wood } \\
\text { structure, } 2 \text { points; the other, } 1 \text { points; } \\
\text { (3) Symmetry: for plane , symmetry , } 1 \text { point, asymmetric , } 0 \text { point; for elevation, symmetry, } \\
0.5 \text { points, asymmetry, } 0 \text { points; } \\
\text { (4) Construction time: } Y \geqslant 2000,1 \text { point ; } 1990 \leqslant Y<2000,0.5 \text { point; } Y<1990,0 \text { point ; } \\
\text { (5) Height } / \mathrm{m}: \mathrm{h} \leq 3.6,2 \text { points; } 3.6<h \leq 7.2,1.5 \text { points; } 7.2<h \leq 10.8,1 \text { point; } 10.8<h, 0.5 \text { point; }\end{array}$ \\
\hline $\begin{array}{l}\text { Fire safety } \\
\qquad U_{12}\end{array}$ & $\begin{array}{l}\text { 1) Fire protection system: for fire performance of decorative materials, A level , } 2.5 \text { points; A1 } \\
\text { level , } 2 \text { points ; A2 level , } 1.5 \text { points, B1 level ,1 point ; B2 level , } 0.5 \text { point ; B3 level , } 0 \text { points; } \\
\text { for ventilation and smoke exhaust system, natural ventilation , } 1 \text { point; mechanical exhaust, } \\
0.5 \text { point; } \\
\text { (2) Fire extinguishing system: if has fire alarm device, } 1 \text { points; if has fire extinguishers, } 1 \\
\text { points; } \\
\text { (3) Safe evacuation system: safe exit, } 1.5 \text { points ; ordinary export , } 0.5 \text { points; emergency } \\
\text { indicator or lighting, } 1 \text { point; } \\
\text { (4) Management and others: strong personnal fire awareness , } 2 \text { points ; normal fire } \\
\text { awareness , } 1 \text { point; }\end{array}$ \\
\hline $\begin{array}{l}\text { Water } \\
\text { security } \\
\mathrm{U}_{13}\end{array}$ & $\begin{array}{l}\text { (1)water quality: no color, } 2 \text { points; no smell , } 2 \text { points ; no precipitation, } 2 \text { points, otherwise } \\
0.5 \text { point; } \\
\text { (2) water pipes, valves, buried pipe: no rust, } 1 \text { points otherwise } 0.5 \text { point; no leakage, } 1 \text { points, } \\
\text { otherwise } 0 \text { points; } \\
\text { (3) sewage treatment: organized sewer row , } 1 \text { points; disorderly row , } 0.5 \text { points; }\end{array}$ \\
\hline $\begin{array}{l}\text { Electric } \\
\text { securit } \\
U_{14}\end{array}$ & $\begin{array}{l}\text { (1) Line design: for line spacing, orderly, } 1 \text { point, messy, } 0.5 \text { point ; for wire connection, } \\
\text { galvanized copper joints , } 1 \text { point, sheep eye joints , } 0.5 \text { points; for the wire section, meet the } \\
\text { load power , no fever , } 2 \text { points, fever, } 0 \text { point; } \\
\text { (2) Grounding safety: bathroom, kitchen , etc. equipotential connection, } 1 \text { point; } \\
\text { (3) Line protection: the protection measures of short circuit, overload, leakage, } 2 \text { points; } \\
\text { (4) The degree of line aging: within } 10 \text { years , } 1.5 \text { points; } 20 \text { 10 years, } 1 \text { point; more than } 20 \\
\text { years, } 0.5 \text { point ; } \\
\text { (5) Electrical safety awareness: no behavior about private pull chaos, the use of fake and } \\
\text { shoddy electrical behavior , } 1.5 \text { points; }\end{array}$ \\
\hline $\begin{array}{c}\text { Daily } \\
\text { security } \\
U_{15}\end{array}$ & $\begin{array}{l}\text { ials: for the durability life, more than } 20 \text { years, } 3 \text { points; } \\
\text { ars, } 1 \text { point ; } \\
\text { if has } 2 \text { points, otherwise } 1 \text { points; } \\
\text {, otherwise } 1 \text { point; }\end{array}$ \\
\hline $\begin{array}{c}\text { Wind } \\
\text { environme } \\
U_{21}\end{array}$ & $\begin{array}{l}\text { (1) Outdoor natural wind environment under typical wind speed and wind direction: } \\
\text { Winter: on the pedestrian zone around the building, the wind speed is less than } 5 \mathrm{~m} / \mathrm{s} \text {, and the } \\
\text { outdoor wind speed amplification coefficient is less than } 1.5,2 \text { points; } \\
\text { Transition and summer season : no appear vortex or calm on people activity area, } 2 \text { points; the } \\
\text { wind speed of the main function room within } 0.5 \sim 1.4 \mathrm{~m} / \mathrm{s}, 1 \text { point; } \\
\text { (2) Indoor natural wind environment under typical wind speed and wind direction: } \\
\text { Transition and summer season : the wind speed of the main function room within } 0.5 \sim 1.4 \\
\mathrm{~m} / \mathrm{s}, 4 \text { points, within } 0 \sim 0.5,1.4 \sim 2 \mathrm{~m} / \mathrm{s}, 3 \text { points, and other , } 1 \text { point; }\end{array}$ \\
\hline
\end{tabular}




\begin{tabular}{|c|c|c|c|c|c|c|c|c|c|c|}
\hline $\begin{array}{l}\text { Hot and } \\
\text { humid } \\
\text { environment } \\
\mathrm{U}_{22}\end{array}$ & \multicolumn{10}{|r|}{$\begin{array}{l}2 \\
\text { en }\end{array}$} \\
\hline $\begin{array}{c}\text { Light } \\
\text { environment } \\
U_{23}\end{array}$ & \multicolumn{10}{|c|}{$\begin{array}{l}\text { (1) Outdoor vision: front and rear direct spacing greater than } 15 \mathrm{~m} \text {, get a score of } 3 \text {; greater } \\
\text { than } 8 \mathrm{~m} \text {, get a score of } 2 \text {; other points; } \\
\text { (2)Window to floor ratio of the bedroom and sitting room, more than } 1 / 5,5 \text { points; } 1 / 6 \sim 1 / 5,3 \\
\text { points; the other, } 1 \text { points; or directly measured indoor illuminance: for living room (hall), } \\
\text { bedroom, study, kitchen, room center natural, illumination value is more than } 300 \mathrm{Ix}, 3 \text { points; } \\
\text { for toilet, lobby, staircase, Dining Center, illuminance value is more than } 150 \mathrm{~lx}, 2 \text { points; } \\
\text { (3) Measures of glare control, if has , } 2 \text { points; }\end{array}$} \\
\hline \multirow{6}{*}{$\begin{array}{l}\text { Acoustic } \\
\text { environment } \\
U_{24}\end{array}$} & \multicolumn{5}{|c|}{$\begin{array}{l}\text { Outdoor acoustic } \\
\text { environment } A(d B)\end{array}$} & \multicolumn{4}{|c|}{$\begin{array}{l}\text { Intdoor acoustic environment } \\
\text { (bedroom ) } \mathrm{B}(\mathrm{dB})\end{array}$} & \\
\hline & Daytime & $\begin{array}{c}0 \sim 5 \\
5\end{array}$ & $55^{\sim 60}$ & $60 \sim 65$ & $\begin{array}{l}> \\
65\end{array}$ & $\begin{array}{c}0 \sim 4 \\
0\end{array}$ & $\begin{array}{c}40^{\sim} 42 . \\
5\end{array}$ & $\begin{array}{c}42.5 \sim 4 \\
5\end{array}$ & $45 \sim 50$ & \\
\hline & Score & 4 & 3 & 2 & 1 & 4 & 3 & 2 & 1 & \\
\hline & Night & $\begin{array}{c}0 \sim 4 \\
5\end{array}$ & $45^{\sim 50}$ & $50 \sim 55$ & $\begin{array}{l}> \\
55\end{array}$ & $\begin{array}{c}0 \sim 3 \\
0\end{array}$ & $\begin{array}{c}30 \sim 33 . \\
5\end{array}$ & $\begin{array}{c}33.5 \sim 3 \\
7\end{array}$ & $37 \sim 40$ & \\
\hline & Score & 5 & 4 & 3 & 2 & 5 & 4 & 3 & 2 & \\
\hline & \multicolumn{10}{|c|}{ Note: the score is a sum of $A$ and $B, A, B$ is a smaller value between day and night. } \\
\hline $\begin{array}{l}\text { Air quality } \\
\qquad U_{25}\end{array}$ & \multicolumn{10}{|c|}{$\begin{array}{l}\text { (1) The annual average value of PM2.5: } \leq 50 \mathrm{mg} / \mathrm{m}^{3}, 2 \text { points, } 35^{\sim} 50 \mathrm{mg} / \mathrm{m}^{3}, 1 \text { point; } \\
\text { (2) The hour average value of formaldehyde : } \leq 0.08 \mathrm{mg} / \mathrm{m}^{3}, 2 \text { points }, 0.08 \sim 0.12 \mathrm{mg} / \mathrm{m}^{3}, 1 \\
\text { point; } \\
\text { (3) The hour average value of radon : } \leq 200 \mathrm{~Bq} / \mathrm{m}^{3}, 2 \text { points; } 200^{\sim} 400 \mathrm{~Bq} / \mathrm{m}^{3}, 1 \text { point; } \\
\text { (4) The hour average value of ammonia : } \leq 0.20 \mathrm{mg} / \mathrm{m}^{3}, 2 \text { points; } 0.20^{\sim} 0.50 \mathrm{mg} / \mathrm{m}^{3}, 1 \text { point; } \\
\text { (5) The hour average value of benzene : } \leq 0.09 \mathrm{mg} / \mathrm{m}^{3}, 2 \text { points; } 0.09 \sim 0.12 \mathrm{mg} / \mathrm{m}^{3}, 1 \text { point; }\end{array}$} \\
\hline $\begin{array}{c}\text { Infrastructure } \\
U_{31}\end{array}$ & \multicolumn{10}{|c|}{$\begin{array}{l}\text { 1) Public activity places like fitness places, supermarkets: if has , } 3 \text { points; } \\
\text { (2) Centralized treatment places like waste water, garbage: if has , } 2 \text { points; } \\
\text { (3) Public lighting of residential road : if has , } 3 \text { points; } \\
\text { (4) The distance from the house to the bus station, less than } 500 \mathrm{~m}, 2 \text { points, } 500 \sim 1000 \mathrm{~m}, 1 \\
\text { point; }\end{array}$} \\
\hline $\begin{array}{l}\text { Indoor } \\
\text { facilities } \\
U_{32}\end{array}$ & \multicolumn{10}{|c|}{$\begin{array}{l}\text { (1) Air conditioner : if has , } 3 \text { points; } \\
\text { (2) Photoelectric adjustment: if has , } 3 \text { points; } \\
\text { (3) The use of solar hot water: if has , } 4 \text { points; }\end{array}$} \\
\hline $\begin{array}{l}\text { Activity } \\
\text { space } U_{41}\end{array}$ & \multicolumn{10}{|c|}{$\begin{array}{l}\text { (1) Courtyard area } S: S \geqslant 20 \mathrm{~m}^{2}, 4 \text { points, } 10 \mathrm{~m}^{2} \leqslant \mathrm{~S}<20 \mathrm{~m}^{2}, 3 \text { points; } \mathrm{S}<10 \mathrm{~m}^{2}, 2 \text { points; } \\
\text { (2) Room function layout: if it is conform to the local culture, } 3 \text { points, otherwise } 1 \text { point ; } \\
\text { (3) Public activity places like the temples, ancestral halls, theaters, etc. } 3 \text { points ; }\end{array}$} \\
\hline $\begin{array}{l}\text { Habits and } \\
\text { customs } U_{42}\end{array}$ & \multicolumn{10}{|c|}{$\begin{array}{l}\text { (1) Courtyard houses, courtyard style houses, building style houses, if it is with , } 4 \text { points, } \\
\text { otherwise } 1 \text { point; } \\
\text { (2) The housing pattern, color, decoration and sculpture New Year paintings : if it reflects the } \\
\text { local traditional culture, } 3 \text { points ; otherwise } 1 \text { point; } \\
\text { (3)The details of the housing structure like eaves, pick layer, screen head, base, door signs etc.: } \\
\text { if it reflects the local traditional culture, } 3 \text { points, otherwise } 1 \text { point; }\end{array}$} \\
\hline
\end{tabular}

\section{The evaluation of rural housing performance}

Set up: the weight of second index $\mathrm{U}_{\mathrm{i}}$ is $\omega_{i}$; the weight of third index $\mathrm{U}_{\mathrm{ij}}$ is $\omega_{i j}$, corresponding sub score of it is $Q_{i j}$.

The weight of the housing performance indicators is determined by Grey-AHP ${ }^{[8]}$. Specific as follows. The weights of first index are $\omega^{1}=\left(\omega_{1}, \omega_{2}, \omega_{3}, \omega_{4}\right)=(0.412,0.281,0.160,0.147)$;

The weights of first index are $w_{1}^{2}=\left(\omega_{11}, \omega_{12}, \omega_{13}, \omega_{14}\right)=(0.298,0.172,0.220,0.231,0.079)$; $w_{2}^{2}=\left(\omega_{21}, \omega_{22}, \omega_{23}, \omega_{24}\right)=(0.258,0.264,0.255,0.111,0.112) ;$ 
$w_{3}^{2}=\left(\omega_{31}, \omega_{32}\right)=(0.523,0.477) ;$

$w_{4}^{2}=\left(\omega_{41}, \omega_{42}\right)=(0.444,0.556)$ 。

The final score is : $\mathrm{W}=\sum_{i=1}^{4}\left(\omega_{i} \sum_{i=1-4}^{j} \omega_{i j} Q_{i j}\right)$

\section{Conclusion}

(1) The rural housing performance evaluation index is proposed , including four second level index and twelve third level indicators.

(2) The performance index is quantized by a lot of investigation, combining with the standards, building physics, the numerical value of to provide quantitative basis for the evaluation.

(3) The weight of the housing performance indicators is determined by Grey-AHP.

\section{Acknowledgments}

This work was financially supported by National Science and Technology Support Project of China (2015BAL02B02), National Natural Science Foundation of China (51408267) , Natural Science Foundation of the Jiangsu Higher Education Institutions of China（14KJB560005）, Energy saving projects in Colleges and universities in Jiangsu Province (JSSNZH2016301), Graduate Student Practical Innovation Program of 2015 Year in Jiangsu Province （SJLX15_0501）.

\section{References}

[1] Chen Rao. Study on water ecological history experience of South of Jiangsu traditional villages and towns planning. Jiangsu urban planning, 2013, (6):6-10.

[2] Zeng Jian, Yang Wei, Wang Zhu. The sustainable development of rural human settlements theory, National Natural Science Fund Committee -- a case study of the development strategy of 2011-2020 special subject China Academy of Sciences (in architecture, environment and Civil Engineering) M. Chinese Building Industry Press, 2011.

[3] Liu Jiaping et al. Building physics [M], Beijing: China Architecture and Building Press, 2009.

[4] GB50033-2013 "standard for daylighting design of buildings" [S], Beijing: China Architecture and Building Press, 2012.

[5] GBT 50824-2013 "rural residential building energy efficiency design standards" [S], Beijing: China Architecture and Building Press, 2012.

[6] GB50011-2010 "code for seismic design of buildings" [S], Beijing: China Architecture and Building Press, 2012.

[7]GB/T 50378-2014 "green building evaluation standard" [S], Beijing: China Architecture and Building Press, 2012.

[8] Xiao Xinping, Song Zhongmin, Li Feng. Basic and application of ash technology [M]. Beijing: Science Press, 2005: 204 - 209. 